\title{
Arcybiskup Życiński a transplantologia
}

Prof. NADZW. DR HAB. EWA KUCHARSKA

Akademia Ignatianum

\section{Wprowadzenie}

Patrząc na rozwój współczesnej medycyny, a także obserwując ciągłe wydłużanie się średniej przeżycia naszych pacjentów, rola transplantologii i problemy z nią związane stają się jeszcze bardziej aktualne i wymagające większej uwagi niż w minionych latach. Tematyka transplantacji znana była już w czasach starożytnych. Problem ten przewijał się ciągle w refleksji filozofów i duchownych. Uważano, iż choroby i zranienia są pod Boską kontrolą, zaś zastąpienie lub regeneracja uszkodzonych części ciała pozostawała ciągle jako zjawisko nadprzyrodzone ${ }^{1}$.

Pomimo większej wiedzy i ciągłej edukacji na temat transplantacji narządów próba uzyskania narządów do

1 N.L. Tilney, Przeszczep. Od mitów do rzeczywistości, tłum. B. Barczyński, Warszawa 2009, s. 30-32. 
przeszczepów jest nadal ogromnie trudna. Dlatego też potrzeba zaangażowania całego społeczeństwa i ciągłego jego edukowania.

Tematyka transplantologii wzbudza w nas refleksję zarówno natury medycznej, jak i etycznej. Wiąże się to z niezwykłą złożonością problemu, a także potrzebą podjęcia go z perspektywy dorobku nauk medycznych oraz filozoficznej refleksji w jej etycznym odniesieniu.

Świadomość społeczna konieczności przekazywania narządów lub tkanek osobom tego wymagającym (potrzebującym) jest wciąż zbyt mała. Natomiast ciągła potrzeba uświadamiania ludziom idei transplantacji oraz jej konkretnych wymiarów w zakresie ratowania życia i zdrowia osób dotkniętych różnego typu chorobami wiąże się ze zbyt małym zrozumieniem konieczności przeszczepów i zbyt wąskim ujęciem definicji transplantacji.

\section{Rys historyczny rozwoju transplantologii}

Transplantologia jest dziedziną nauk medycznych, która rozwinęła się w odpowiedzi na nieudane próby przeszczepień różnych narządów w celu poszukiwania wyjaśnień niepowodzeń przeszczepów. Początki współczesnej transplantologii sięgają pierwszych lat XX wieku, a jednym z jej prekursorów był Alexis Carrel, który opracował technikę zespoleń naczyniowych. Należy zauważyć, iż modelowym narządem do przeszczepu z racji swojej budowy stała się nerka. Już od lat trzydziestych XX wieku 
przeprowadzono wiele prób przeszczepienia nerek zwierzęcych ludziom, a pierwszą próbę przeszczepu ludzkiej nerki człowiekowi podjął w 1933 roku chirurg rosyjski J. J. Woronoj. W latach 1947-1952 w USA, Kanadzie i Francji przeprowadzono dalsze nieudane próby podobnych zabiegów. Sukcesem na tym etapie rozwoju transplantologii było opracowanie techniki operacyjnej używanej do czasów obecnych i jednocześnie stwierdzenie, że przyczyną niepowodzeń był brak podobieństwa organizmów dawcy i biorcy. Pierwsze udane przeszczepienie ludzkiej nerki człowiekowi wykonano w 1954 roku w USA. Dokonali tego Joseph E. Murray i John P. Merrill $^{2}$. Od tej pory $\mathrm{w}$ wielu ośrodkach na całym świecie z sukcesem dokonywano zabiegów na polu transplantologii różnych narządów.

Pomijając szczegółową analizę danych odnoszących się do rozwoju transplantologii w poszczególnych okresach historycznych od starożytności, poprzez średniowiecze, do bliższych nam czasów (temu wiele uwagi poświęcają tacy autorzy jak: Joseph E. Murray3; Francis D. Moore4; B. Te-

2 Zarys chirurgii transplantacyjnej, red. W. Rowiński, J. Wałaszewski, Warszawa 1993; R. Kuss, P. Bourget, An Illustrated History of Organ Transplantation, Ruel-Malmaison 1992.

3 Current Evaluation of Human Kidney Transplantation, ed. J.E. Murray et al., 1965, [on-line] http://onlinelibrary.wiley.com/doi/10.1111/ j.1749-6632.1965.tb30684.x/abstract [dostęp: 20.03.2017].

4 F.D. Moore, A Miracle and a Privilege: Recounting a Half Century of Surgical Advance, Washington D.C. 1995. 
ratti ${ }^{5}$ czy R. Richardson ${ }^{6}$ ), warto przytoczyć następujące fakty i daty mające wpływ na dalszy rozwój transplantologii na przykładzie Polski, gdzie osiągnięcia w tej dziedzinie są znaczące w skali świata.

Już w styczniu 1966 roku prof. Jan Nielubowicz wykonał po raz pierwszy w Polsce udany zabieg przeszczepienia nerki pobranej od osoby zmarłej. Biorczynią była uczennica szkoły pielęgniarskiej, leczona i przygotowywana do zabiegu przez profesora Tadeusza Orłowskiego w Klinice Chorób Wewnętrznych Akademii Medycznej w Warszawie. W owym czasie przeszczepianie narządów nie było jeszcze powszechnie przyjętym sposobem leczenia, a na całym świecie wykonano zaledwie 620 takich operacji

Dwa lata później (1968) prof. Tadeusz Bross we Wrocławiu wykonał bardzo podobny zabieg, przeszczepiając nerkę pobraną od dawcy, który był spokrewniony genetycznie z biorcą. Od tego momentu wydawało się, że przeszczepianie nerek stanie się w Polsce w krótkim okresie rutynowym sposobem leczenia chorych z przewlekłą, schyłkową niewydolnością tego narządu. Niestety tak się nie stało, chociaż problem był nadal aktualny. Utrudniały to istniejące $w$ drugiej połowie lat sześćdziesiątych $\mathrm{XX}$ wieku przepisy prawne obowiązujące na terenie Polski.

5 B. Teratti, Transplantation and reimplantation in the arts, Surgary 1974.

6 R. Richardson, Transplanting teeth, "Lancet” 1999.

7 W. Rowiński, Aspekty prawne i etyczne przeszczepiania narządów, „Służba Zdrowia”, 26-30.09.2002. 
Pomimo dużej wiedzy na temat koncepcji śmierci mózgowej, rozpoznanie zgonu w oparciu o te kryteria było w Polsce prawnie niedopuszczalne. Dopuszczalne zaś było pobieranie tkanek od zmarłych. Pobieranie nerki od osoby zmarłej odbywało się jako pierwszy akt badania pośmiertnego - które obowiązywało w przypadku zgonu pacjenta w szpitalu.

Pobranie jednej nerki od zdrowego żywego dawcy było aktem bezprawnym. Nieustanna praca profesorów Jana Nielubowicza, Tadeusza Orłowskiego oraz Leszka Kubickiego porządkowała program pobierania nerek od osób zmarłych, a także rozpoczęto próby przeszczepiania nerki pobranej od żywego dawcy. Niezwykle istotnym stał się fakt, iż w 1971 roku prof. Jan Mol wykonał jako pierwszy w Polsce (Łódź) i jeden z nielicznych na świecie przeszczepienie serca pobranego od osoby zmarłej. Wzbudziło to ogromne kontrowersje zarówno w środowisku lekarskim, jak i prawniczym. Efektem było zatrzymanie programu przeszczepiania nerek w Łodzi. Ciągle była nadzieja na to, iż mimo wielu sprzeciwów metoda przeszczepów jednak się przyjmie.

Świat medyczny napotykał także opór społeczeństwa, gdyż pobieranie narządów od zmarłych uważano za niemoralne, a w społeczeństwie nie rozumiano konieczności ratowania życia przez dokonanie przeszczepu narządu od drugiego człowieka. Mimo tych wszystkich problemów w Warszawie kontynuowano program przeszczepiania nerek, wykonując najpierw po kilka, a później po kilkanaście 
zabiegów w ciągu roku. W latach osiemdziesiątych XX wieku powstało też w Polsce kilka nowych ośrodków zajmujących się przeszczepami nerek ${ }^{8}$.

Prawdziwy przełom to pierwszy udany w Polsce zabieg przeszczepienia serca wykonany w 1986 roku przez prof. Zbigniewa Religę w Zabrzu. Było to niezwykłe dlatego, iż w Polsce nadal nie istniały uregulowania prawne określające sprawę pobierania narządów od zmarłych przy bijącym sercu, po komisyjnym rozpoznaniu śmierci mózgu?.

Poza sukcesami dotyczącymi transplantacji nerek i serca, kolejne sukcesy to udane jednoczesne przeszczepienie nerki i trzustki w roku 1989 przez J. Szmidta i M. Lao. Następne przeszczepy to przeszczep trzustki u osoby z uprzednio przeszczepioną nerką $\mathrm{w}$ roku 2004, a w 2005 roku przeszczepienie obu płuc, 2006 rok przyniósł pierwszy przeszczep wątroby i jelita, a 2008 rok - przeszczep komórek wyspowych trzustki w układzie auto- $\mathrm{i}$ allogenicznym ${ }^{10}$.

\section{Definicja i rodzaje transplantacji organów}

Samo pojęcie transplantacji pochodzi z języka łacińskiego i odwołuje się do słowa transplantare, czyli przesadzać, przenosić. Pod pojęciem transplantacji rozumiemy także metodę leczenia za pomocą wymiany tkanek lub całych organizmów.

\footnotetext{
8 N.L. Tilney, Przeszczep. Od mitów do rzeczywistości, dz. cyt., s. 11.

9 Tamże, s. 12.

10 Tamże, s. 15-16.
} 
Jest to metoda ratowania życia chorego, który potrzebuje zdrowego narządu, by żyć. Przeszczepianie to postępowanie operacyjne polegające na przeniesieniu tkanki lub narządu w miejsce brakującego narządu, ubytku lub uszkodzenia prowadzącego do daleko posuniętej niewydolności ${ }^{11}$.

Każdego roku w Polsce na przeszczepienie narządu oczekuje bardzo wielu chorych. Często jest to dla nich jedyna szansa na powrót do normalnego funkcjonowania, a nierzadko nawet na przeżycie. Transplantacja to uznana i skuteczna metoda leczenia dająca szansę na powrót do zdrowia.

Pomimo ciągłej edukacji pacjentów i poruszania tematu transplantologii w aspekcie społecznym, w Polsce brakuje narządów pobieranych od zmarłych dawców do przeszczepów nerek, serc, wątroby i innych.

\section{Rodzaje przeszczepów}

Wyróżniamy dwa rodzaje przeszczepów

a) Pobieranie i przeszczepianie komórek, tkanek i narządów pochodzących ze zwłok;

b) Pobieranie komórek tkanek, narządów od żywego człowieka $^{12}$.

11 Słownik wyrazów obcych i zwrotów obcojęzycznych, red. W. Kopaliński, Warszawa 1989, s. 521; Słownikjęzyka polskiego, red. M. Szymczak, t. 3, Warszawa 1984, s. 525.

${ }_{12}$ Hexal podręczny leksykon medycyny, red. N. Boss, Wrocław 1996, s. 711. 
Rozróżniamy transplantację ex mortus i ex vivo. Transplantacja ex mortus zachodzi wówczas, gdy transplant pozyskuje się ze zwłok, zaś ex vivo, gdy dawcą przeszczepu jest żywy człowiek. Transplantacja ex mortus jest ściśle związana z pobieraniem komórek, tkanek lub narządów ze zwłok ludzkich zarówno w celach diagnostycznych, leczniczych, jak też naukowych i dydaktycznych. Przesłankami tego rodzaju transplantacji są śmierć mózgowa dawcy, brak istnienia sprzeciwu dawcy wobec przeszczepu oraz zasadność medyczna.

Transplantacja ex vivo jest szeroko stosowaną formą ratowania życia, w której dawcą danego narządu, tkanki lub komórki jest osoba żyjąca.

Podstawowymi problemami występującymi w tym typie transplantacji są procesy immunologiczne, które występują przy przeszczepach genetycznie różnych od organizmu biorcy. Tolerancja przeszczepu jest możliwa tylko w wypadku przeszczepów synergicznych (pochodzących od dawców identycznych genetycznie). Jeśli zaś dawca różni się genetycznie, konieczna jest modyfikacja układu immunologicznego. Możemy tego dokonać poprzez równoczesne przeczepienie komórek odpornościowych lub też przez zastosowanie przeciwciał bądź leków hamujących czynność układu odpornościowego ${ }^{13}$.

13 E. Kucharska, R. Nęcek, Transplantacja jako troska o życie i zdrowie bliźniego, „Przegląd Lekarski” t. 68 (2011) nr 12, s. 1210. 
W mechanizmach genetycznych, które warunkują przyjęcie przeszczepu, bardzo istotne są antygeny zgodności tkankowej. Układ antygenów HLA to antygeny zgodności tkankowej, które dzielimy na dwie klasy:

Klasa I - antygeny grup A, B i C;

Klasa II - antygeny grupy D (DR, DQ, DP, DO).

Dla celów transplantacyjnych oznacza się antygeny grupy A, B oraz DR. Łącznie odnosi się to do 6 antygenów (po 2 w każdej grupie), które w zróżnicowany sposób determinują skuteczność i powodzenie przeszczepów. Z badań wynika, że największy wpływ na sukces transplantacyjny mają antygeny grupy $\mathrm{DR}$, najmniejszy zaś grupy $\mathrm{A}^{14}$.

Zarówno jeden, jak i drugi rodzaj transplantacji (ex mortus, ex vivo) są jednakowo ważne, gdyż dają możliwość ratowania życia konkretnej osobie ludzkiej. Ważne jest przy tym, aby proces pozyskiwania narządów do transplantacji odbywał się w zgodzie z zasadami etyki lekarskiej oraz obowiązującą regulacją prawną. Nie bez znaczenia jest tu świadomość i odpowiedzialność zarówno po stronie biorcy, jak i dawcy narządów ratujących zdrowie i życie ludzkie.

W Polsce zdecydowana większość przeszczepianych narządów pobierana jest od osób zmarłych w mechanizmie śmierci mózgu. Liczba przeszczepień narządów pobranych od osób żyjących jest dramatycznie mała, zważywszy na

14 Hexal podręczny leksykon medycyny, dz. cyt., s. 31; Choroby wewnętrzne. Podręcznik dla studentów, red. F. Kokot, Warszawa 1996, s. 411. 
deklarowane powszechnie przywiązanie do więzi rodzinnych i chrześcijańskie korzenie naszej kultury. Jako społeczeństwo nadal mamy problem $\mathrm{z}$ akceptacją śmierci mózgu jako śmierci człowieka oraz pobierania narządów od osoby bliskiej zmarłej. Na przeszkodzie akceptacji śmierci mózgu jako śmierci człowieka często stoi niewiedza, którą karmi się brak zaufania z jednoczesnym sprzeciwem kierowanym nie wobec transplantacji jako takiej, ale wobec śmierci bliskiej osoby, z którą rodzina zmarłego musi się nagle skonfrontować. Narządy i tkanki do przeszczepienia pobierane są ze zwłok osób, które za swojego życia nie wyraziły sprzeciwu. Do tkanek i narządów najczęściej przeszczepianych obok nerki, wątroby, serca i płuc należą także trzustka, jelito, szpik kostny, skóra, tętnica i rogówka.

\section{Transplantologia w Polsce}

W 2003 roku w przeliczeniu na 1 milion Polaków pobrano narządy od 13,7 dawców. Z danych statystycznych wynika, iż stan transplantologii w Polsce, wyniki i przeżycie pacjentów po przeszczepach są takie same jak w ośrodkach europejskich i amerykańskich ${ }^{15}$. Są jednak różnego rodzaju bariery, które różnią nasz kraj od innych, np. etyczne i obyczajowe. Ogromny wpływ na kształtowanie postaw rodzin dawców i ich samych mają opinia Kościoła i media. Niezwykle istotną sprawą jest zaangażowanie zespołów

15 P. Wróbel, Transplantologia w Polsce, „Rynek Zdrowia” nr 4 (2005). 
lekarskich, zwłaszcza w sytuacji, kiedy mamy do czynienia z ludzką tragedią. Najwięcej pobrań jest tam, gdzie zespół szpitala budzi zaufanie u pacjentów i ich rodzin, gdzie zgodnie z najnowszą wiedzą medyczną przewiduje się, jakie są rokowania, i przygotowuje rodzinę do ewentualnej śmierci bliskiej osoby. Wyjaśnienie rodzinie pacjenta wielu problemów (np. stopnia uszkodzenia mózgu, możliwości terapeutycznych podobnych przypadków), posługiwanie się doświadczeniem medycznym, budowanie dobrych kontaktów z rodziną potencjalnego dawcy są elementami kwalifikacji zawodowych bardzo cennymi w tej dziedzinie.

Niezwykle często w kontekście trudności związanych z procedurami transplantacji mówi się o kłopotach logistycznych, słabej edukacji społecznej, zbyt małym zaangażowaniu części środowiska medycznego. W Polsce barierą są także koszty niektórych procedur, np. procedura przeszczepu wątroby i prowadzenie pacjenta w pierwszym roku po zabiegu to koszt ok. 200 tys. zł. Najwięcej narządów w przeliczeniu na 1 milion populacji pobiera się w szpitalach województw: zachodniopomorskiego, opolskiego, dolnośląskiego, mazowieckiego, zaś najmniej w województwach: podkarpackim, podlaskim i lubelskim oraz małopolskim ${ }^{16}$.

Istotną rolę w pozyskiwaniu dawców odgrywa koordynator zatrudniony w szpitalu. Jest on odpowiedzialny za poszukiwanie dawców oraz sposób uświadomienia ich

16 Tamże. 
o znaczeniu i roli przekazania wartościowych narządów osobom potrzebującym. Jego kompetencje merytoryczne i społeczna wrażliwość oraz postawa wobec pacjentów decydują o efektach podejmowanych działań. Każdy pozyskany narząd oznacza szansę ratowania zdrowa i życia konkretnego człowieka, stąd misja, jaka towarzyszy działalności koordynatora, jest wyjątkowa.

Kryteria, jakimi posługuje się współczesna medycyna, nie służą do ustalenia dokładnego momentu śmierci, są naukowo pewnymi środkami określenia biologicznych oznak świadczących o tym, że człowiek naprawdę umarł. Śmierci się nie orzeka, stwierdza się, że nastąpiła. Śmierć mózgu oznacza śmierć człowieka polegającą na całkowitym rozpadzie zjednoczonej i zintegrowanej całości, jaką jest człowiek, mimo że funkcjonują jeszcze poszczególne narządy, zachowana jest czynność serca i ciepłota ciała. Dzieje się to za sprawą sztucznego podtrzymywania ich funkcji. U osób, u których podejrzewa się śmierć mózgu, ordynator OIOM-u lub lekarz specjalista przez niego upoważniony wykonuje dwie serie badań neurologicznych i próbę bezdechu. Komisja lekarska złożona $\mathrm{z}$ trzech lekarzy, w tym z co najmniej jednego specjalisty w dziedzinie anestezjologii i intensywnej terapii oraz jednego specjalisty w dziedzinie neurologii lub neurochirurgii, stwierdza śmierć mózgu w celu odłączenia osoby zmarłej od aparatury wentylującej. Przed odłączeniem aparatury należy rozpatrzyć możliwość pobrania niektórych narządów do przeszczepu. Pozostaje wtedy 
tylko kilka godzin, aby upewnić się co do woli zmarłego dotyczącej oddania tkanek i narządów po śmierci. Wymaga to sprawdzenia w Centralnym Rejestrze Sprzeciwów, czy dana osoba nie zarejestrowała sprzeciwu na pobranie narządów po śmierci. Zgodnie z polskim prawem każda zmarła osoba może być uważana za potencjalnego dawcę tkanek i narządów, jeśli za życia nie wyraziła sprzeciwu. Lekarze, pod opieką których był zmarły, informują rodzinę o śmierci i zamiarze pobrania narządów do przeszczepienia, ale nie muszą prosić jej o wyrażenie na to zgody. Jeśli zmarły pozostawił pisemny zapis dotyczący jego woli odnośnie do pobierania narządów po śmierci lub ustną informację, zostaje to uszanowane. Bliscy mogą wówczas jedynie potwierdzić opinię zmarłego na temat pobrania narządów, jeśli wcześniej ją znają. W polskim ustawodawstwie istnieje pojęcie zgody domniemanej, jest to założenie mówiące o tym, że jeśli ktoś za życia nie złożył swojego sprzeciwu wobec pobrania narządów i tkanek, to wyraził na takie pobranie zgodę. Wyrażenie woli o zgodzie na pobranie narządów po śmierci to inaczej oświadczenie woli. Osoba wyrażająca zgodę na oddanie po śmierci swoich tkanek i narządów dla ratowania życia i przywracania zdrowia ludziom chorym, może także nosić przy sobie własnoręcznie podpisane oświadczenie woli. Taki dokument ma charakter informacyjny i nie zwalnia lekarza, mającego zamiar pobrać narządy, z obowiązku sprawdzenia w Centralnym Rejestrze Sprzeciwów, czy osoba ta nie wyraziła sprzeciwu 
za życia. Swoją decyzję należy przekazać swoim najbliższym. Decyzję o oddaniu narządów po śmierci podejmuje potencjalny pacjent samodzielnie. Nie możemy obciążać nią osób bliskich ani pozostawiać ich w niepewności co do naszych poglądów. Zgodnie z ustawą transplantacyjna z 1 lipca 2005 roku pobrania komórek, tkanek i narządów ze zwłok ludzkich, można dokonać, jeżeli osoba zmarła nie wyraziła za życia sprzeciwu. Sprzeciw należy zgłosić osobiście lub listownie w Centralnym Rejestrze Sprzeciwów w Centrum Organizacyjno-Koordynacyjnym ds. Transplantacji „Poltransplant” w Warszawie. Po dokonaniu wpisu w Centralnym Rejestrze Sprzeciwów osoba zgłaszająca otrzymuje listem poleconym potwierdzenie wpisu. Sprzeciw jest skuteczny od daty wpisu do rejestru, który będzie uwidoczniony na potwierdzeniu. Moc prawną ma także noszone przy sobie własnoręcznie podpisane oświadczenie sprzeciwu lub oświadczenie ustnie złożone w obecności dwóch świadków i pisemnie przez nich potwierdzone. Przed przeszczepieniem danego narządu wykonuje się całą gammę badań, których celem jest wykluczenie jakiejkolwiek choroby dawcy. Choroba ta mogłaby być przeniesiona do biorcy przeszczepu. Pobieranie narządów do przeszczepiania jest operacją chirurgiczną wykonywaną w warunkach bloku operacyjnego, w czasie której ciało dawcy winno być traktowane z należytym szacunkiem. Biorcy danych narządów nigdy nie poznają nazwiska dawców, ponieważ dar narządów od zmarłego jest anonimowy i altruistyczny. Wyraźnie 
zabroniony jest, a wręcz karalny, handel narządami. Aby uniknąć ryzyka, obowiązujące przepisy prawne przewidują, że przeszczepieniem narządów mogą zajmować się jedynie upoważnione ośrodki medyczne. Przeszczepianie narządów jest bardzo skomplikowaną procedurą wymagającą zachowania określonych standardów medycznych.

\section{Pozyskiwanie narządów do przeszczepu i ich kryteria}

Proces pozyskiwania narządów do transplantacji wymusił wprowadzenie regulacji prawnych. Przeprowadzanie przeszczepów musi być zgodne z merytoryczną wiedzą medyczną, jak i normami prawa stanowionego. Do roku 1975 problematyka przeszczepów w Polsce nie była uregulowana, a podejmowane działania w tym zakresie opierano wyłącznie na wiedzy i sztuce medycznej. Dopiero w roku 1975 ukazały się wytyczne Ministra Zdrowia i Opieki Społecznej w sprawie zabiegu przeszczepiania nerek. Były one stosowane przez analogię do innych narządów przez wiele lat. W roku 1991 uchwalono ustawę o zakładach opieki zdrowotnej, która porządkowała kwestię transplantacji, odnosząc się do organów pobieranych ze zwłok ${ }^{17}$. Kompleksową regulację prawną dotyczącą transplantacji wprowadziła dopiero ustawa z dnia 26 października 1995 roku o pobieraniu, przeszczepianiu komórek, tkanek

17 Ustawa z dnia 30 sierpnia 1991 roku o zakładach opieki zdrowotnej, tekst jednolity, Dz. U. 2007 nr 14 poz. 89 z późn. zm. 
i narząadów ${ }^{18}$. Obejmowała ona kwestie transplantacji zarówno ex mortus, jak i ex vivo.

Przystąpienie Polski do grupy państw członkowskich Unii Europejskich warunkowało zmiany w zakresie regulacji prawnej i wymusiło wprowadzenie przepisów zgodnych z zasadami i przepisami prawa obowiązującego na terenie Unii Europejskiej. Konsekwencją tego było uchwalenie nowej ustawy dotyczącej transplantacji, ustawy z dnia 1 lipca 2005 roku o pobieraniu, przechowywaniu i przeszczepianiu komórek, tkanek i narządów. Reguluje ona kwestie związane zarówno z przeszczepami ex mortus, jak i ex vivo. Określa w szczególności zasady dotyczące transplantacji ludzkich organów. Monika Brzozowska wyróżnia na tej podstawie dziewięć przewodnich zasad warunkujących legalność procesu pozyskiwania komórek, tkanek i narządów do transplantacji. Określają one reguły pozyskiwania, przechowywania, przetwarzania, przeszczepiania, testowania narządów z ciał osób zmarłych, a także obowiązki personelu medycznego względem dawców i biorców. Regulują one również zakazy związane z przyjmowaniem korzyści materialnych (tzw. handel narządami).

W obecnej sytuacji prawnej każda transplantacja ma na celu ratowanie życia osoby ze skrajną schyłkową niewydolnością danego narządu. Współcześnie napotykamy wiele problemów wynikających z różnych przyczyn, takich

18 Ustawa z dnia 26 października 1995 roku o pobieraniu, przeszczepianiu komórek, tkanek i narządów, Dz. U. 1995 nr 138 poz. 682 z późn. zm. 
jak: długa lista oczekujących, odpowiedni dobór dawcy i biorcy (całkowita zgodność immunologiczna, tj. dawca i biorca muszą być identyczni pod względem genetycznym, np. w przypadku szpiku), przeszczep jako skomplikowane przedsięwzięcie organizacyjne, ograniczenia światopoglądowe dawców i biorców, trudności finansowe współczesnej służby zdrowia.

Istnieją ściśle określone kryteria, jakie musi spełniać potencjalny dawca. Nie pobiera się narządów od osób zakażonych wirusami (HIV), bakteriami czy grzybami, osób, które chorowały na nowotwory złośliwe, miażdżycę uogólnioną czy choroby immunologiczne, a także takie choroby, które mogły doprowadzić do uszkodzenia poszczególnych narządów. Istnieją także ograniczenia wiekowe będące przeciwwskazaniem do pobrania, a więc jest to wiek powyżej 70 lat. Przeciwskazaniem są także takie choroby jak nadciśnienie tętnicze czy cukrzyca bądź nadużywanie środków farmakologicznych, alkoholu czy innych używek prowadzących do zniszczenia organów.

Przykładowo: nerki pobiera się do transplantacji według ściśle określonych zasad. Są to: wiek - od 7 dni do 70 roku życia dawcy, brak przewlekłych chorób nerek dawcy.

W przypadku zaś serca kryteriami doboru są: wiek - poniżej 50 roku życia, brak rozległych uszkodzeń klatki piersiowej, brak chorób serca, krótki czas pobytu na OIOM-ie.

Dawcą narządów może być także ofiara wypadku. Kryterium śmierci będzie wówczas ostateczne zatrzymanie akcji serca. Stosowane jest także w transplantologii 
kryterium śmierci mózgowej, które zostało zaakceptowane przez polskie prawo i obowiązuje od 1996 roku.

Najczęściej przeszczepianym narządem jest nerka. Nerkę przeszczepia się osobie z trwałą utratą czynności nerek własnych, co najczęściej jest następstwem ich przewlekłej choroby. Celem przeszczepu jest poprawa funkcjonowania oraz wydłużenie życia pacjenta. Przeszczep nerki w odróżnieniu od przeszczepu serca czy wątroby, jest tylko w wybranych przypadkach zabiegiem ratującym życie, alternatywną metodą leczenia do dializoterapii. Przeszczepienie nerek to niezwykle istotna, a wręcz optymalna metoda leczenia chorych ze schyłkową niewydolnością. Pacjenci leczeni hemodializą lub dializami otrzewnowymi mogą po przeszczepie nerki zaprzestać dializ. Pozwala to na ich powrót do aktywności życiowej sprzed choroby, mogą normalnie pracować, podróżować i uprawiać sport, co poprawia ich komfort życia. Przeszczepianie nerki znacząco zmniejsza ryzyko zgonu pacjenta, u którego dokonano przeszczepu, w porównaniu z chorym przewlekle dializowanym. Warto także podkreślić, iż pacjentki w wieku rozrodczym po transplantacji nerki mają znacznie większą szansę na zajście w ciążę i prawidłowy jej przebieg. Podobnie u dzieci, u których dokonano przeszczepu nerki, przebieg i rozwój jest prawidłowy. Najlepszym rozwiązaniem jest przeszczep narządu pochodzącego od dawcy żywego, spokrewnionego z biorcą, nerka przeszczepiona od dawcy żywego funkcjonuje dłużej niż nerka od dawcy zmarłego, co związane 
jest $\mathrm{z}$ doborem immunologicznym. Warto zwrócić uwage na fakt, iż przeszczepienie nerki i opieka nad chorym po transplantacji amplifikuje w systemie ochrony zdrowia dużo mniejsze koszty w porównaniu z wieloletnią dializoterapią i leczeniem powikłań dializoterapii. Przed dokonaniem przeszczepu każdy dawca poddany jest wielu specjalistycznym badaniom, co niejednokrotnie daje możliwość wykrycia wielu schorzeń występujących u dawcy. Zapoczątkowuje to u nich proces diagnostyczno-leczniczy, a jednocześnie wyklucza z grona dawców. Kandydatom na dawców należy wyjaśnić, iż oddanie przez nich nerki nie wpływa u nich na konieczność zmiany trybu życia. Dawca po dokładnym zbadaniu i przeprowadzeniu badań laboratoryjnych i obrazowych zostaje zakwalifikowany do oddania narządu, w tym wypadku nerki. Cała diagnostyka i jej wyniki objęte są tajemnicą lekarską, co dotyczy również potencjalnego biorcy. Jeśli dawca na którymkolwiek etapie zrezygnuje z decyzji bycia dawcą narządów, nie ponosi kosztów przeprowadzonej diagnostyki. Jeśli zaś wyniki badań wykluczą możliwość bycia dawcą, biorcę informuje się, że dany dawca jest nieodpowiedni, nie podając szczegółów. Pierwsze pobranie nerki w celu jej przeszczepienia, które zakończyło się pełnym sukcesem, miało miejsce w 1954 roku w USA. Było to pobranie nerki od żywego dawcy. Dawcą był Ronald Herrick, który oddał nerkę swojemu bratu bliźniakowi. Ronald zmarł w 2010 roku, mając 79 lat, a więc 56 lat po oddaniu swojej nerki bratu. Każdy dawca otrzymuje formularz świadomej 
zgody w momencie zakwalifikowania go do przeszczepu i podpisuje go przed zabiegiem. Biorca zobowiązany jest do przestrzegania zaleceń dotyczących odpowiedniego trybu życia, a także konieczności współpracy z zespołem przeszczepowym i informowania go o niepokojących objawach. Każda osoba po dokonaniu przeszczepu poddana jest leczeniu immunosupresyjnemu, które jest konieczne, aby nie doszło do odrzucenia przeszczepionego narządu. Warto zauważyć, iż stosowane leczenie immunosupresyjne powoduje większą podatność na infekcję, dlatego też dochodzi do zakażeń wirusowych zwłaszcza w pierwszych sześciu miesiącach po przeszczepie narządu. Jednym z najczęściej występujących zakażeń wirusowych po przeszczepie narządu jest zakażenie wirusem cytomegalii, a także niejednokrotnie wirusem opryszczki, półpaśca, ospy wietrznej czy też zakażeń grzybiczych wywołanych grzybem Candida. Obok zakażeń wirusowych dochodzi do zakażeń bakteryjnych, szczególnie zakażeń dróg moczowych, a także innych narządów. Podczas zakażeń układ immunologiczny biorcy bakterie i wirusy rozpoznaje jako obce dla organizmu i reaguje przeciwko nim, w taki sam sposób rozpoznając przeszczepioną nerkę, dlatego też układ immunologiczny biorcy, próbując zniszczyć obce ciało, odrzuca nerkę. W celu zapobiegania temu procesowi stosujemy leki immunosupresyjne, które osłabiają taki proces. Każdy drobny symptom świadczący o odrzucenia nerki wymaga zazwyczaj hospitalizacji i szerokospektralnego leczenia, gdyż wcześnie wykryte 
próby odrzucenia mogą być zniwelowane leczeniem. Leki immunosupresyjne mogą także zwiększać ryzyko wystąpienia cukrzycy czy choroby nadciśnieniowej.

Współczesna medycyna poprzez swoją wiedzę daje nam możliwość stosowania różnych metod leczenia, a jedną z nich jest transplantologia. Istotny jest fakt, by ludzkość umiejętnie korzystała z odkrywanego potencjału naukowego. Łatwo bowiem można przekroczyć granice, co spowoduje, że działania podejmowane z myślą o dobru pacjenta mogą przynieść negatywne efekty.

\section{Transplantacja jako forma miłości bliźniego}

Każda ingerencja medyczna musi brać pod uwagę integralną całość pacjenta, na którą składa się jedność między duchem a ciałem. Oznacza to także, iż ciało nie jest jedynie częścią osoby, ale nieodłącznym elementem całości, któremu przysługuje nietykalność i należny szacunek. Z tej racji medycyna będąca wiedzą i sztuką lekarską zobowiązana jest do traktowania pacjenta jako podmiotu leczenia. Dlatego relacja pacjenta i lekarza winna przyjąć postać współuczestnictwa i współodpowiedzialności ${ }^{19}$. Wyraźnie mówi o tym Karta Pracowników Służby Zdrowia: „praktyczne spotkanie i synteza wymagań oraz zadań, jakie wynikają z pojęć zdrowia i służby zdrowia, stanowią podstawę

19 Por. W. Gubała, Problemy moralne związane z leczeniem choroby nowotworowej, „Analecta Cracoviensia” nr 32 (200o), s. 117-118. 
i drogę do humanizacji medycyny. Powinna być ona rozwijana zarówno w zakresie osobowo-zawodowym (relacja lekarz-pacjent), jak również w wymiarze społeczno-politycznym, by bronić w strukturach instytucjonalnych i technologicznych interesów ludzko-chrześcijańskich w społeczności oraz infrastruktur instytucjonalnych i technologicznych"20.

Dlatego też pacjent nie może być traktowany jako materiał doświadczalny w eksperymentach medycznych i sprowadzony do roli banku organów w zabiegach transplantacyjnych ${ }^{21}$, lecz winien być traktowany jako podmiot „cywilizacji miłości i życia, bez których egzystencja osób i społeczeństwa traci swój sens najbardziej ludzki"22.

\section{Komunikacja z pacjentem}

Sukces diagnostyczno-terapeutyczny może zostać osiągnięty jedynie pod warunkiem dobrej komunikacji pacjenta z jego lekarzem czy też innym pracownikiem służby zdrowia. Lekarz winien postrzegać pacjenta w ujęciu holistycznym, a więc widzieć nie tylko jego wymiar cielesny, ale także duchowy. Niejednokrotnie zdarza się fakt, iż poznajemy

20 Papieska Rada ds. Duszpasterstwa Służby Zdrowia. Karta Pracowników Służby Zdrowia, nr 9.

${ }^{21}$ W. Gubała, Problemy moralne związane z leczeniem choroby nowotworowej, dz. cyt., s. 119.

${ }_{22}$ Papieska Rada ds. Duszpasterstwa Służby Zdrowia. Karta Pracowników Służby Zdrowia, nr 9. 
człowieka fragmentarycznie, co nie daje dobrej możliwości jego zdiagnozowania i leczenia. Lekarz traktujący pacjenta holistycznie podejmuje współpracę z pacjentem, a także z przedstawicielami różnych dyscyplin naukowych, w ten sposób pomagając choremu w postawieniu odpowiedniej diagnozy. Zawód lekarza jest bowiem misją wymagającą cierpliwości, zrozumienia, zaangażowania i otwartości na drugiego człowieka. Zgodnie z tym, co mówił ojciec św. Benedykt XVI podczas swojego przemówienia do przedstawicieli Papieskiej Akademii, „Naukowcy nie mogą myśleć, że mają w rękach bezduszną i plastyczna materię" ${ }^{23}$.

\section{Współczesne problemy transplantologii}

Aktualnie transplantologia jako dziedzina medycyny ratująca życie chorych napotyka wiele problemów. Jak już wspomniano, należą do nich: brak organów do przeszczepów, długa lista oczekujących, konieczność odpowiedniego doboru dawcy i biorcy zgodnych immunologicznie, a także trudności finansowe współczesnej służby zdrowia. Procedury związane z przeszczepem narządów są niezwykle kosztowne, a w kontraktach z NFZ są one niedofinansowane. Koszty wykonywanych przeszczepów przewyższają nakłady dysponowane na jeden przeszczep dla każdego

23 Benedykt XVI, Przemówienie do uczestników zgromadzenia ogólnego Papieskiej Akademii "Pro Vita” (13.02.2010), „L'Osservatore Romano” 5 (2010), s. 21. 
pacjenta. Istotnym problemem jest zbyt mała edukacja pacjenta. Pacjenci niejednokrotnie nie rozumieją, czym jest dokonanie przeszczepu i jak cenną rolę odgrywają narządy pobrane ze zwłok dawcy dla biorcy w ratowaniu jego życia. Podobnie w przypadku dawców żywych społeczeństwo nie posiada wyczerpującej wiedzy dotyczącej braku wskazań i przeciwskazań do przeszczepu. Dlatego też zainicjowanie kampanii „Drugie życie” i zachęcanie do wypełnienia oświadczenia woli o podarowaniu narządów jest niezwykle istotne i cenne. Zaangażowanie mediów, a także całego społeczeństwa, w tym duchownych, umożliwia lepsze zrozumienie faktu przekazania narządów do przeszczepów, co daje możliwość wzrostu świadomości społecznej w zakresie transplantologii.

\section{Arcybiskup Życiński a transplantologia}

Konieczność oddawania narządów do przeszczepów doskonale rozumiał abp Józef Życiński. Metropolita lubelski w liście pasterskim czytanym w niedzielę w kościołach Lubelszczyzny zachęcał do pobierania i wypełniania deklaracji woli. Arcybiskup powoływał się na nauczanie papieża Jana Pawła II, podkreślając, „iż oddanie narządów do przeszczepu po naszej śmierci stanowi ważny akt miłości bliźniego, przejaw wielkodusznej solidarności i szlachetny czyn zasługujący na szczególne uznanie"24. Według me-

${ }^{24}$ J. Życiński, Transplantologia, „Wprost”, 24.06.2007. 
tropolity lubelskiego wypełnione deklaracje staną się znakiem chrześcijańskiej odpowiedzialności za życie kogoś zagrożonego, kto dzięki przekazywanym po czyjeś śmierci organom będzie mógł żyć i działać ${ }^{25}$. Arcybiskup przypominał, że Polska znajduje się na dalekim miejscu pod względem liczby osób deklarujących gotowość do przekazania organów w przypadku śmierci, liczba ta dramatycznie maleje. "Ci z nas, którzy wypełnią tę deklarację, dając wyraz chrześcijańskiej miłości bliźniego, niechaj zachowają wypełniony tekst wśród ważnych osobistych dokumentów. W ten sposób będziemy mogli nieść nadzieję silniejszą od zagrożenia śmiercią, budując cywilizację miłości nawet w obliczu śmierci" ${ }^{26}$.

Arcybiskup Życiński wielokrotnie w swojej cotygodniowej audycji Pasterki Kwadrans w archidiecezjalnym radiu podkreślał, że choć według polskiego prawa istnieje domniemanie zgody na pobranie organów na przeszczep (a osoby temu przeciwne zgłaszają to w Centralnym Rejestrze Sprzeciwów), to Katechizm Kościoła katolickiego wymaga, aby zgoda była jednoznacznie wyrażona. „Od katolików można wymagać więcej” - twierdził metropolita lubelski. Z jego inspiracji zakupiono ok. 80 ooo kart i deklaracji ${ }^{27}$. Jako osoba wszechstronnie wykształcona, współpracująca ze światem medycznym, znająca potrzeby

\footnotetext{
25 Gazeta pl., 16.04.2005.

26 J. Życiński, Transplantologia, „Wprost”, 24.06.2007.

${ }_{27}$ Tamże.
} 
współczesnej medycyny, Arcybiskup angażował się w różne akcje mające na celu promowanie zdrowego stylu życia, a także szeroko pojętej profilaktyki. Prowadzone przez niego działania pomogły w uświadomieniu roli transplantologii jako dziedziny medycyny ratującej życie człowieka. 